AperTO - Archivio Istituzionale Open Access dell'Università di Torino

\title{
On the role of government in promoting altruism
}

\section{This is the author's manuscript}

Original Citation:

Availability:

This version is available http://hdl.handle.net/2318/1618363

since 2018-10-29T17:55:03Z

Published version:

DOI:10.1108/IJSE-02-2015-0041

Terms of use:

Open Access

Anyone can freely access the full text of works made available as "Open Access". Works made available under a Creative Commons license can be used according to the terms and conditions of said license. Use of all other works requires consent of the right holder (author or publisher) if not exempted from copyright protection by the applicable law. 


\title{
On the role of government in promoting altruism
}

\author{
Enrico Colombatto $^{(a)}$ and Valerio Tavormina ${ }^{(b)}$
}

\begin{abstract}
Purpose: The purpose of this paper is to discuss whether altruism justifies ad-hoc legislation with reference to three different contexts. One is defined by the libertarian notion of liberty, a second framework corresponds to the egalitarian vision, and a third one originates from social-contract theory. Methodology and finding: the authors review two stylized vision of liberty, and consider to what extent the current legal systems comply with one of the se visions. Moreover, the authors analyse the implications of the contractarian approach. Findings: It is shown that current legislation is rather ambiguous and sometimes even contradictory. By and large, the common-law view tends to favour the libertarian approach, while the civil-law visions are closer to what one might expect from social-contract theory. In these cases, however, it seems that the letter of the law is often questioned by the academic community as well as by the judiciary, and decisions eventually follow the judges' discretionary power. Originality and value: This analysis of altruism combines the economic and legal perspectives.

Although altruism is always considered an important part of social capital and worthy of privileged treatment, it is shown that policymaking is frequently inconsistent and sometimes contradictory.
\end{abstract}

JEL Classification codes: D64, K19, K39

Key words: Justice, Liberty, Institutions and institutional analysis, Social goods, Legal institutions, Altruism.

We are grateful to Leonardo Baggiani, Niclas Berggren, Ron Cass and Giovanni Ramello for their valuable comments on previous drafts of this paper.

(a) Professor of Economics, ESOMAS, Università di Torino, Italy (enrico.colombatto@unito.it), corresponding address.

(b) Professor of Law, Università Cattolica del Sacro Cuore, Milano, Italy (valerio.tavormina@unicatt.it). 


\section{On the role of government in promoting altruism}

\section{An introduction to the economics of altruism}

Each individual follows a conscious desire to be better off, and evolves into "the different person that he must become as he acquires knowledge and wisdom" (Buchanan 1979: 97). In other words, individuals are certainly self-interested: they choose and act with a view to enhancing their happiness. However, they are also altruistic, when their behaviour makes other people happier and, as a result, the benefactors' satisfaction grows. In other words, altruism is an acquired or inherited disposition $^{1}$ that leads a conscious individual (the benefactor) to operate in order to benefit, at least in part, other individuals (the beneficiaries); because by doing so he improves his own welfare. Thus, altruistic action includes two elements. Each benefactor acts in order to improve his own satisfaction (self interest); and at least part of the satisfaction the actor experiences derives from his knowing that the beneficiary is better off.

Altruism has been the object of a rather rich economics literature that harks back to the Impartial Spectator typical of the Scottish enlightenment (Raphael 2007; Khalil 2001). ${ }^{2}$ It was then revived by Becker (1974), and further extended by Andreoni (1989); more recently, altruism has also been the object of a rich experimental literature (Levitt and List, 2007). Briefly put, economists have developed an interest in altruism for two reasons. First, it has been observed that altruism is a source of positive externalities, a term that designates a desirable outcome produced by an actor who has borne the costs of production but has failed to appropriate all the benefits he has created. In particular, "altruism" refers to situations in which the failure to internalize the externalities is intentional. In other words, and in contrast with the other positive externalities, altruistic behaviour requires that an individual consciously and willingly operates to benefit other 
people. Within this context, the social benefits of altruism are those accruing to the donor -- self-satisfaction for having been charitable and for having possibly become the object of the recipients' gratefulness - and those accruing to the beneficiary. ${ }^{3}$ Therefore, one could claim that spontaneous altruism tends to be less than socially desirable, since spontaneous altruism stops when the giver's marginal satisfaction equals his marginal sacrifice (reduced consumption). Government intervention could thus be desirable if it encourages altruistic behaviour to the point at which the marginal cost incurred by the producer and the marginal benefits generated by the producer and enjoyed by society are equal. Of course, the social benefits of altruism include the satisfaction enjoyed by donor A (this is the "private benefit"), and the satisfaction enjoyed by beneficiary B (the positive externality). ${ }^{4}$

A second source of interest for the economics profession regards "civility", a notion that was known at least since the $15^{\text {th }}$ century and is now usually called "social capital", a synonym for "trust" and "reputation". 5 In short, it is argued that since the presence of altruism reveals appreciation for people in need and a fair disposition towards the rest of the community, altruism enhances economic cooperation, strengthens social cohesion, and ultimately promotes growth (Haines 1981 and Ridley 1996). This mechanism is further strengthened by the fact that the beneficiaries of altruism realize that by being good citizens they are likely to encourage altruistic behaviour by the other members of the community - givers and potential givers. Thus, altruism could be seen as a selfreinforcing phenomenon that encourages exchange, enhances growth, and defuses social tensions by promoting civility. The opposite applies when altruism is lacking, and civility is weak.

To summarize, the economic view on altruism leads to three conclusions: Altruism tends to be in short supply, it enhances economic growth, and it is characterized by selfreinforcing or self-destructive mechanisms. Following from these claims, legislators are tempted to intervene in the interest of the common good by resorting to two instruments: tax exemptions and legal privileges.

\subsection{Tax exemptions}


At first glance, tax breaks on the portions of income and wealth spent on altruistic transactions should meet unqualified approval: such breaks encourage desirable activities and do not alter the donor's control on the allocation of resources.

However, tax breaks suffer from two shortcomings. First, tax-deductible altruism can originate abuses (tax evasion), especially when exemptions involve transactions among individuals, rather than institutions. For example, individual A might buy hard to monitor personal services (e.g. house cleaning or real estate renovation) from individual $\mathrm{B}$, and pretend that at least part of the payment is in fact a donation: A would benefit from the tax break and, if donations are tax free for the beneficiary, B would avoid income taxation.

A second shortcoming regards the opportunity cost of the tax break. A fiscal exemption on the portion of income devoted to altruistic expenditure requires that general taxation increases to compensate for the drop in revenues due to the tax break, and/or that government expenditure is cut in order to match the lower tax revenues. In the case of compensating taxation, however, it is not obvious that the benefits generated by the rise in altruism are greater than the costs related to the distortions and to the potential drop in altruism provoked by a higher tax pressure and, therefore, by lower disposable incomes. ${ }^{6}$ Likewise, if the policymaker starts from a context characterized by "optimal" government expenditure, and prefers to maintain general taxation constant, how does he know whether the benefits of additional altruism - including greater civility -overcompensate for the welfare losses (social inefficiencies) generated by the expenditure cuts?

In other words, social-welfare maximization and -- more generally -- consequentialism ${ }^{7}$ are weak justifications for tax breaks. The main reason is that most of the benefits and costs involved are subjective, and utilitarian accounting is necessarily arbitrary.

\subsection{Legal privileges and duties}

The introduction of legal privileges guaranteeing preferential treatment to altruistic behaviour also requires some caution. Today's prevailing approach to socially-optimal 
legislation follows the Posnerian law-and-economics insights by suggesting that one should consider the benefits generated by the altruistic actions the policymaker intends to favour, compare them with the costs inflicted upon those whose rights are violated, and then legislate with a view to maximizing social wealth (Holmes 1897 and Posner 1979).

However, arguing in favour of privileges by appealing to the notion of social wealth is yet another form of consequentialism, and suffers from the same weaknesses mentioned earlier. First, one needs to justify social efficiency as a legitimate and overarching goal, which is not self-evident. Moreover, the benefits and costs involved are to some extent subjective. Hence, they are impossible to measure and compare.

In this paper, we discard the Posnerian, social-welfare maximizing criterion, and consider policymaking with regard to altruism by adopting a standpoint dear to the political-philosophy tradition. In particular, we identify the source of legitimacy for normative action in the realms of moral principles (sections 2 to 4 ) and social contracts (section 5). Moral principles and social contracts will then be applied to one specific set of altruistic actions: the invasion of somebody's physical integrity and private property in the interest of a third party. For example, how should one consider an individual who cracks somebody else's car to take an injured man to hospital? Or a medical doctor who uses violence to remove a strip of skin or a pint of blood from a reluctant donor in order to save a third party? Or a climber that provokes the fall of his companion in order to save other members of the team?

Different legal systems offer a variety of possible answers, which are based on dissimilar lines of reasoning and are questioned even from within. For example, the letter of the Italian criminal code justifies all the actions mentioned above. ${ }^{8}$ Yet, legal scholars argue that one should admit invasions of physical property, and exclude personal violations (Grosso 1977: 890; Romano 1995: 538-539; Mezzetti 1997: 12-13). In this light, only the first situation (cracking the car) would be allowed. Judges have usually followed the scholarly view; ${ }^{9}$ but not always. For example, they followed the letter of art. 54(1) and acquitted a doctor who successfully removed an organ from a 
patient without having previously informed him, ${ }^{10}$ and another doctor who had transferred blood to a Jehovah's witness who had opposed the transfusion, but had subsequently lost consciousness. ${ }^{11}$

By contrast, common-law systems are more restrictive, and they generally punish those who violate the rights of a third person in order to help a needy individual. However, even common-law rulings admit exceptions. For example, the Court of Appeals of England and Wales accepted the request of a hospital, whose doctors wanted to terminate one Siamese twin to save the other, despite opposition from the parents. ${ }^{12}$

\section{Moral a prioris: the libertarian view}

As mentioned above, morality competes with consequentialism as the framework within which one can evaluate the nature and legitimacy of legal rules. Of course, each individual has his own set of moral aprioris, shaped by instinct, education, experience, and possibly history. This explains why sweeping generalizations are impossible. Yet, the analysis can be narrowed down and simplified by observing that the moral standards characterizing a community are in fact a mix of two visions. These are the libertarian and the egalitarian views, which differ according to the notion of liberty they adopt. We shall examine them in turn, in this section and in the following one.

Briefly put, libertarians advocate a negative notion of liberty, which is usually known as "freedom from coercion". According to the freedom-from-coercion principle, each individual has the right to be free from any kind of physical aggression or threat of such an invasion. This principle also applies to private property, which cannot be violated. ${ }^{13}$ Certainly, this general rule includes contract enforcement, since it is assumed that ownership is acquired as a consequence of the contract and that, therefore, breach of contract amounts to theft. Put differently, an individual A who has voluntarily entered a contract has a duty to keep his word, even if he has changed his mind after having agreed to the terms of the contract, especially if he has already received, or acquired a right to receive, a remuneration. ${ }^{14}$ The same applies to situations in which $\mathrm{A}$ is about to violate B's own freedom from coercion. Hence, violent action by B is justified against 
A's assault: theft, taxation, expropriation, and fraud. In all these cases, violent defensive action is accepted if it is targeted to forestall the aggressor, and if the threat is realistic. Overreaction is equivalent to an unjustified act of aggression by victim B against the initial offender A: the roles would be reversed.

Are the privileges awarded to altruism - tax breaks and legal privileges -- consistent with the libertarian notion of freedom? May one argue that when altruistic behaviour is at stake, basic libertarian principles are a sound basis to pass legislation in favour of altruistic deeds?

Libertarians consider taxation a gratuitous violation of private property. Hence, a tax privilege is in fact equivalent to a reduction in the extent of the violation, a reduction that the government owes to all citizens, not only to altruists. In a similar vein, there is no room for exceptions to the norms that protect private property. Put differently, from the libertarian standpoint, the freedom-from-coercion principle does not apply to different degrees depending on the altruistic nature of the individual's action. In particular, government $\mathrm{G}$ is not allowed to treat individuals $\mathrm{A}, \mathrm{B}$ or $\mathrm{C}$ differently just because A means well or, more generally, because A's behaviour is a source of positive externalities for some members of the community. To conclude, tax breaks are always welcome, as long as they are financed through expenditure cuts, rather than higher taxes on the rest of the taxpayers. It is not clear, however, whether altruistic individuals should be the first beneficiaries of a tax-break programme.

Likewise, since nobody has a right to obtain goods or services against the giver's will, nobody has a duty to give or act in the interest of another party. In other words, there is no room for mandatory solidarity. In a similar vein, therefore, a third party is not entitled to force an individual to engage in altruistic activities, neither directly ( $\mathrm{G}$ forces A to operate in favour of $B$ ) nor indirectly ( $G$ takes resources from $A$ and gives them to B).

The previous line of reasoning applies to situations in which altruism conflicts with one's freedom from coercion. What kind of behaviour would the libertarian vision 
suggest, however, when the freedom-from-coercion principle can only be enforced through altruistic actions? For example, imagine that an individual $\mathrm{C}$ attacks individual B's physical integrity or property. Has individual A an obligation to intervene, as many legislations suggest, especially when the government agencies in charge cannot forestall the invasion? Or would it be just an option that individual A can pursue or discard as he pleases? Put differently, does an individual have a duty to intervene whenever a basic moral principle is violated? And what are the boundaries of such intervention?

The libertarian would answer that although it would be highly desirable that A came to the rescue of B, A cannot be held liable for failing to do so (see Leoni 1961: 54; Rothbard 1982: chapter 14; De Jasay 2002: chapters 16-17; Mack 2008). In other words, the libertarian does not advocate pure self-interest and stonehearted disregard for people misfortunes. Nonetheless, the libertarian draws a line between the duties one has as a member of a community, and the duties one has towards his own conscience. The former are virtually nil, unless they are part of an explicit contract (e.g., services provided by a fire-fighting company), while the latter are clearly a subjective matter. It would be highly desirable if all human beings were nice and generous. But a libertarian does not feel entitled to sanction an individual A only because he is intrinsically evil, unless evil behaviour manifests itself as an act of invasion, imminent aggression or complicity in aggression. In other words, B's dislike for the personality of A does not justify B's encroachment upon A's freedom.

The libertarian view is indeed present in the common law tradition, fittingly summarized by Lord Nicholls of Birkenhead: "the recognized legal position is that the bystander does not owe the drowning child or the heedless pedestrian a duty to take steps to save him. Something more is required than being a bystander. There must be some additional reason why it is fair and reasonable that one person should be regarded as his brother's keeper and have legal obligations in that regard". ${ }^{15}$

On the other hand, civil-law countries are ambiguous. Civil-law codes do mention mandatory intervention, but with important qualifications. For example, art. 125 of the Russian criminal code prescribes mandatory assistance to individuals whose life or 
health are in danger, but only if the person in danger is under the direct responsibility of the potential rescuer, or if the danger has been provoked by the potential rescuer. In Italy, an individual can abstain from assisting people in danger if he notifies the police immediately (art. 593 crim. code). In France (art. 223-6 e 223-7 crim. code) and in Spain (art. 195 crim. code), assistance is mandatory only if it does not involve any kind of personal risk; while in Germany assistance is mandatory only in the absence of serious risk ( $\S 323 \mathrm{c}$ crim. code). The inconsistency of these norms is apparent: how can one exclude mandatory intervention in the presence of risk, but also abstain from sanctioning a killer who acts in order to help a third party?

To summarize, it seems that legislators are not hostile to the libertarian standpoint, and that when mandatory altruism is present, it is subject to qualifications and interpretations. This has consequences, as we can observe by analyzing another category of situations: the limits to altruistic intervention. In this light, let us imagine that Bob has been aggressed, and that despite the absence of a contract that obliges Andrew to come to the rescue, Andrew decides to help Bob in forestalling the attack. How far can Andrew go in helping Bob to defend himself? Unless Bob puts a limit to Andrew's action (Bob can of course reject Andrew's altruistic offer to help), ${ }^{16}$ within the libertarian framework the limit to Andrew's action follows the general regime applying to the notion of self-defence, a regime defined by credible threat, proportionality, and necessity. To these notions we now devote our attention.

When is a threat credible? And who decides about credibility? A child waving a toy gun and asking his parents a few coins to buy an ice cream on a crowded beach can hardly represent a credible threat to his parents' physical integrity. Things can be more serious, however, if a young man with a mask on his face waves a dark-coloured plastic gun in front of short-sighted tourist in a Sao Paolo favela or in a Mogadishu suburb. The advocates of the libertarian position argue that the burden of proof regarding credibility falls upon the potential victim: when reacting violently to the attack, the victim - the child's parents or the tourists, in our examples -- must demonstrate that the aggressor's behaviour could indeed be perceived as hostile, regardless of the aggressor's true intentions. The same principle applies to those running to the victim's rescue. Following 
up on our example, therefore, we can conclude that a bystander has no duty to intervene when somebody is under threat in a Sao Paolo favela. His intervention is certainly desirable, but it ultimately depends on the individual's conscience, on his guess about the victim's willingness to be rescued, and on his (the rescuer's) evaluation of the circumstances (his own perception of the "credible threat"). In other words, the potential helper Andrew is justified in violating Charles' freedom when Charles is attacking Bob, but Andrew bears the burden of proof regarding the credibility of Charles' threat.

However, neither Andrew nor Bob is justified in violating David's freedom in order to forestall Charles' attack, since that would be equivalent to assuming that David is willing to help. And this assumption is unwarranted. Of course, if David is unable to express his consent, and if Andrew and Bob are persuaded that David would indeed be willing to help, they will proceed to violate David's freedom. If they are right, then David will not react and perhaps abstain from suing for the damages that Andrew and Bob might have provoked.

As mentioned above, a second set of comments relates to proportionality. Current legal standards usually require proportionality (i.e. equivalence), between the violence characterizing the attack and the reaction; and also between the value of the defended assets and the value of the assets encroached upon to protect the assets under attack. Yet, real-life situations might not be easy to assess. In many cases, the victim-to-be might imagine the aggressor's intentions, but can only guess how the aggressor is likely to react, should the victim try to defend himself. What if someone is about to steal my car, but I am persuaded that the thief might draw a gun or hit me if I try to stop him? Should proportionality relate to the value of the car? To the physical damage the victim might suffer if the burglar reacts? And how can we assess how valuable the car is to the victim, especially if the car is fraught with sentimental memories?

From a freedom-from-coercion perspective, the victim's reaction can include everything deemed appropriate (i.e. sufficient) to neutralize the perceived threat. Of course, the emphasis is on the subjective perception. Shooting a pickpocket when a push is enough to discourage him is surely inappropriate. Likewise, it is certainly acceptable to fire at a 
pickpocket who shows a knife or reacts and becomes violent after the push; but if the pickpocket simply runs away after having stolen a piece of property, the victim can only run after him (or have somebody else run after him) and force him to return the stolen property.

A final set of comments regards the extension of the right to defend one's own self and to assist other individuals to defend themselves. In particular, such extension applies to situations in which, lacking any third party's assault, one appeals to "necessity" or “extreme necessity” to protect not only one's own physical integrity and private property (which may include personal freedom), but also his honour and other rights. In other words, is need or extreme need equivalent to a credible invasion of the freedomfrom-coercion principle, so that violent actions with the purpose of alleviating such condition of need are equivalent to some kind of self-defence? And can one make a similar argument when honour is at stake, ${ }^{17}$ so that Andrew is legitimized to react and violate an innocent third party's freedom (from coercion) when his (Andrews's) reputation is being harmed?

Need and extreme need are certainly deplorable situations to which civil individuals should pay attention. From the libertarian perspective, however, deprivation does not justify the violation of somebody else's person or property, unless the members of a community have explicitly committed themselves to guaranteeing - say -- a minimum living standard to everybody. Once again, this does not mean that a person should look the other way when he sees a poor human being with little or no food and miserable shelter. Andrew can surely donate to poor Bob, but neither Andrew nor Bob can steal from Charles in order to alleviate Bob's condition (or protect his honour), regardless of whether Charles is evil or rich, or outraged.

\section{Egalitarian aprioris}

In contrast with the libertarian perspective, the egalitarian view maintains that all individuals have the right to obtain the means to realize their potential as human beings. Furthermore, it is argued that the community to which the individual belongs has an 
obligation to make these means available to him/her. In other words, liberty means "liberty to flourish", and corresponds to the right to become what one potentially is. Clearly, the impossibility of defining one's potential, and what one needs in order to realize his potential, makes it hard to transform this general principle into operational legal rules. Egalitarians elide this impediment in two steps. They assume that the liberty to flourish is obtained when all the members of a community have the same opportunities. Moreover, they maintain that this condition is met when individuals' incomes are equal or the income of the poor is not too far below the average income of the community to which he belongs. Following from this, therefore, liberty usually requires substantial redistribution. ${ }^{18}$

In particular, since the egalitarian notion of flourishing actually means "flourishing within the community", the scope of redistribution is less the attainment of a given absolute level of welfare than the reduction of the income inequalities within a given community. ${ }^{19}$

Clearly, the debate on the use of tax privileges to promote altruistic behaviour loses much of its importance within an egalitarian context. Suppose that two individuals -Andrew and Bob -- live in an egalitarian society, and that Andrew intends to donate to Bob. Would it be desirable to encourage/reward Andrew through a tax break?

The answer is in the negative if the community is characterized by income equality: if Andrew donates to Bob, such action is part of Andrew's flourishing (Andrew realizes his charitable nature by donating), and there is no reason why the policymaker should intervene in order to reward one particular kind of flourishing, regardless of how much he admires it. Put differently, the egalitarian vision does not prescribe that all individuals should act in the same way, but rather that the starting position of all individuals be the same. ${ }^{20}$

However, the answer is mixed if Andrew's donation to Bob takes place in a community that does share an egalitarian ideal, but in which income equality has not been obtained. If Andrew belongs to the "rich" group of the population, then no tax break is desirable: 
Andrew's altruism contributes to bringing about the egalitarian ideal. By contrast, if individual Andrew is "poor", tax breaks on altruism contribute to bringing about a better (more egalitarian) society.

What about law making? Since the basic principle of an egalitarian society consists in making sure that all its members enjoy equal opportunities to flourish, flourishing should also be the guiding principle for legislation. Let us develop this line of reasoning by considering the two sets of situations that we used as benchmarks for evaluating lawmaking and altruistic behaviour in the previous section. May Andrew invade Bob in order promote his own (Andrew's) flourishing? Similar to the libertarian case, the egalitarian answer is no, since from an egalitarian perspective, Andrew's aggression on Bob is an infringement upon Bob's freedom to flourish, and therefore morally unacceptable. May Andrew oppose Bob's actions when he (Andrew) perceives that Bob is obstructing his (Andrew's) flourishing? Consistent with the previous argument, the answer is generally in the positive, since flourishing trumps all other considerations, including contractual agreements. For example, the egalitarian jurisprudence shows that the legislator intervenes by regulating hiring and firing in the labour market and by supporting the employee (who is assumed to have fewer opportunities to flourish) in situations featuring unfair treatment by the employer, whatever this term means.

Yet, from an egalitarian perspective dealing with these two benchmark cases - ban on aggression and self-defence -- is not immune from ambiguities. The previous section showed that the libertarian moral standard presents no major ground for conflict, since Andrew's right to be free from coercion does not require that Bob's gives away his freedom from coercion. By contrast, within the egalitarian context it is of course possible to think of situations in which Andrews's flourishing can only unfold at the expense of the flourishing of other members of the community. The dynamics of the labour market and unfettered competition in the marketplace are two clear examples. In other words, whereas the libertarian moral mainstay focuses on the individual, the egalitarian principle blurs the difference between the victim and the aggressor, and ultimately puts forward solutions that require some kind of social accounting (utilitarianism). When the legislator offers privileges to the employee in order to 
enhance his flourishing, the legislator necessarily stifles the employers' flourishing. Likewise, when the legislator blocks a merger or forces a producer to make his technology accessible to his competitors, the flourishing of the innovators is hampered, while the flourishing of the competing producers is enhanced. Hence, the decision on whom should be favoured must necessarily resort to a utilitarian criterion.

What about helping others to flourish or protecting others from aggression (altruism)? One can speculate that all the rich members of an egalitarian society have a duty to help the poor members of that very society: this is the very principle upon which legislators justify taxation and redistribution. Thus, altruism is all but mandatory for the rich, but not for the poor.

The same principle - conditional mandatory altruism -- applies to invasion, with three important caveats. First, given that social accounting necessarily establishes the legitimacy of social interaction, if the aggressor is acting in order to enhance his own flourishing at the expenses of the victim, the potential rescuer must first investigate whose flourishing is more important, and subsequently run the risk of being sanctioned if he makes mistakes. Second, the assessment process outlined above is further complicated by the fact that the notion of flourishing is frequently imperfectly known to the individual, and is ultimately defined by the policymaker. Third, given the relativist notion of flourishing, it is apparent that one has a duty towards the members of his own community, but not towards those of other communities. This disparity might be puzzling unless one succeeds in defining the term "community": is it a country? a municipality? a federal state? Should a rich Parisian care about a poor man in Marseille, or should he give priority to a Parisian beggar? and should he ignore a Bulgarian homeless family, even if Bulgaria belongs to the European Union, which considers itself a community, and welcomes and enforces redistribution from rich to poor countries through a variety of federal programs?

\section{Preliminary conclusions}


Altruism is certainly a desirable feature of human action. However, desirability raises two basic questions. Is altruism desirable enough to justify privileged treatment by the legislator? Are there circumstances under which altruistic behaviour should be considered a duty, rather than a mere option? We have argued that consequentialism does not offer satisfactory answers. It involves arbitrary choices in regard to the goal to be pursued, and it necessarily leads to social accounting, an exercise that has been baffling social scientists since the time Condorcet questioned the foundations and the possibility of social choice.

One alternative to consequentialism consists in referring to shared moral standards. Within this context, we have identified two stereotypes, the libertarian and the egalitarian. The libertarian ideal is based on the notion of freedom from coercion. It claims that altruism justifies no privileges and involves no duties. By contrast, the egalitarian ideal is based on the notions of human flourishing and equal opportunities, the latter being obtained through income and/or wealth redistribution within the community. Under such circumstances, preferential treatment is justified by the differences in the actors' income levels, rather than by the intrinsic desirability of the action. Thus, altruism is acceptable or welcome only after suitable utilitarian accounting has been carried out. The same is true when we consider one's action in favour of another individual, whose self-realization might be in conflict with the flourishing of other members of the community.

The libertarian position is unequivocal, and does not transform a situation of conflicting interests into a social-choice problem. Nonetheless, modern societies are far from libertarian: their members share a notion of fairness that includes egalitarian traits, so that compromising with some social accounting is inevitable. Social-contract theorizing has been the way through which political philosophers have strived to legitimize these compromises, and to limit the eventual discretionary elements typical of decisionmaking. In this light, the next section will analyze the role of altruism within the context of possible social covenants, which tend to combine paternalism and social solidarity. 


\section{Social-contract theorizing}

Briefly put, social-contract theories posit that all individuals are social animals and that, therefore, being part of a community is a trait of their nature. The social contract is the implicit or explicit covenant that defines the scope of the community to which individuals belong, and the relationship between each individual and the rest of the community.

According to some authors, those who do not subscribe to the covenant or opt out of it go against their very nature, and choose to do so only because they intend to exploit or harm the other individuals who are part of it. By staying out of the covenant, these individuals reveal their evil traits. Hence, they lose their human dignity and can be attacked/coerced by the other members of society, who allegedly act to defend themselves against creatures who deserve no mercy.

Other authors think differently, and argue that those who decide to stay out of the covenant and remain in the so-called "Lockean state of nature" (Locke, 1689, Book 2, chapter 2) are not necessarily inhuman, but might simply dislike the existing covenant, or might find it too difficult to join/create a different/new covenant. Put differently, adherence to a covenant must be explicit, opting out of a tacit covenant should be easy (Locke, 1689, Book2, chapter 8, section 121) and diversity and disagreement do not justify aggression.

By definition, those who are part of a political community - either because they have abandoned the Lockean state of nature or because they are implicitly part of a covenant -- are bound by the same legal rules. But how does one define the essence of the covenant and the limits to legislation? Modern democracies have found it expedient to solve the problem by assigning the power to legislate to an elite: the legislators. The legislators are selected according to shared procedures (elections and appointments), so that the notion of legitimacy ultimately becomes a matter of procedure. Put differently, the electoral system ensures that the political elite continuously defines and revises the covenant, which is monitored and possibly replaced if it falls down on the job. ${ }^{21}$ 
Regardless of one's opinions about procedural legitimacy, the democratic solution has garnered wide consensus in many areas of the world. ${ }^{22}$ What does the democratic covenant tell us about altruism, one's duties towards the other members of society and, more generally, one's duties towards other human beings? It is hard to discern general rules. Legislations currently accept that encroachment upon one's physical integrity or property is a crime, but they also add that encroachment is acceptable when carried out by a government agency or authorized by the law. In other words, the libertarian principle is not denied, but it can easily be set aside for egalitarian reasons.

What about altruism within a democratic covenant? Predictably, a system driven by an elite legitimized by elections is bound to produce sets of legal rules that meet the requests of public opinion or of selected interest groups. Legislation regarding altruism is no exception, and since legislators are not constrained by any absolute, everlasting moral benchmark, one can expect legislation on altruism to follow the cultural heritage and the prevailing ideologies of the community to which it applies. In particular, today's procedural covenants induce legislators to follow a few general rules in accord with public opinion:

- Altruism is desirable and worthy of preferential treatment, but less so if the donor is rich;

- No individual has a duty to be altruistic, unless altruism is required/enforced by legislation.

\section{Concluding remarks}

This paper has considered the foundations of legislation on altruism from three different viewpoints, depending on whether one focuses on consequentialism, morality or socialcontract theorizing. Even if adherents to all three philosophical traditions agree that altruism is socially beneficial and that encouraging it is, ceteris paribus, beneficial as well, taking further steps to have government promote altruism encounters serious analytical difficulties. In particular, utilitarian analysis (consequential analysis) has difficulties, while the egalitarian perspective always needs to import utilitarian elements (implicitly or explicitly) if it is to make meaningful choices in a range of settings. 
However, today's societies are neither libertarian nor egalitarian. With regard to altruism and the law, in section 1.2 we have observed that the libertarian vision seems to prevail in common-law countries, in which legislation does not usually give preferential treatment to altruistic behaviour. In particular, it does not allow A to encroach upon individual C's property in order to save B. ${ }^{23}$ By contrast, a different perspective characterizes other legal systems. For example, the Italian criminal code does not rule out encroachment (art. 54 crim. code), and provisions of the same kind may be found in France (art. 122-7 crim. code), Germany ( $\S 34-35$ crim. code), Japan (art. 37 crim. code), Russia (art. 39 crim. code), and Spain (art. 20 crim. code). ${ }^{24}$

In general, modern societies tend to neglect ever-lasting moral standards, and prefer to delegate law making to expendable elites, whose main job is the maintenance of social tranquillity, a target that often leads to populism. In this context, discretionary policymaking follows public opinion, and public opinion ultimately defines what the common interest is.

Altruism is no exception. Not surprisingly, expediency and discretion generate contradictions - both across countries and even within each body of national legislation, (see section 1.2 above). For example, common law countries do not make exceptions when somebody's honour is involved. By contrast, civil-law regimes are more nuanced. For example, art. 384(1) of the Italian criminal code specifies that privileged treatment for crimes aimed at protecting liberty and honour applies only when such crimes are committed against the judiciary (lying) and when the actor or his close relatives are involved. And the German legislation does not prosecute criminal A who acts to protect the honour of B by encroaching upon C, but only insofar as the judge considers that B's interest is worthier that the damage inflicted upon $\mathrm{C}$.

As a result, looking for a consistent approach to altruistic behaviour is illusory. In the future, legislation will of course continue to support altruistic behaviour, although in some countries support will be restrained by egalitarian and budgetary concerns. By contrast, legislators will hardly take into account the connection between civility and 
altruism, since the welfare state has almost crowded out the Smithean impartial spectator, the libertarian actor in charge of remedying manifest misery and suffering. Paternalism and mandatory solidarity will thus prevail, while the notion of individual responsibility will decline. Given the overarching principle of procedural legitimacy and the general propensity to please public opinion, the duty to assist the victim becomes a social obligation, rather than a personal one. In a word, the individual's freedom to act is going to be replaced by the judge's decision on whether the action is appropriate; and the ideal of (social) fairness will supplant civility. 


\section{References}

Andreoni, J. (1989), "Giving with impure altruism: applications to charity and Ricardian equivalence”, Journal of Political Economy, 97 (6), December: 1447-1458. Becker, G. S. (1974), “A theory of social interactions”, Journal of Political Economy, 82 (6), November/December; 1095-1117.

Bjørnskov, C. (2012), "How does social trust affect economic growth?”, Southern Economic Journal, 78 (4), pp. 1346-1368.

Block, W. (2003), "Toward a libertarian theory of inalienability: a critique of Rothbard, Barnett, Smith, Kinsella, Gordon, and Epstein”, Journal of Libertarian Studies, 17 (2): 39-85.

Block, W. (2004), "Libertarianism, positive obligations and property abandonment: children's rights", International Journal of Social Economics, 31 (2): 275-286.

Buchanan, J. M. (1979), What Should Economists do?, Liberty Fund, Indianapolis. Carpenter, J. and Knowles Myers, C. (2007), "Why volunteer? Evidence on the role of altruism, reputation, and incentives”, IZA Working Papers, 3021, Bonn, September. Christie, G. C. (1999), "The defense of necessity considered from the legal and moral points of view”, Duke Law Journal, 48 (5), March: 975-1042.

Congleton, R. D. (2014), “The contractarian constitutional political economy of James Buchanan", Constitutional Political Economy, 25(1), March: pp.39-67.

Crespi, A., Gabrio-Zuccalà, G. (2008): Commentario Breve al Codice Penale, Cedam, Padova.

Grosso, C.F. (1977), "Necessità (dir. pen.)", Enciclopedia del Diritto, XXVII, Giuffré, Milano: 882-898.

Haines, W. W. (1981), “The economic consequences of altruism”, International Journal of Social Economics, 8 (4): 50-69.

Holmes, O. W. (1897), “The path of the law”, Harvard Law Review, 10 (8), March: 457-478.

Hyman, D.A. (2006), "Rescue Without Law: An Empirical Perspective on the Duty to Rescue", Texas Law Review, 84: 653-737.

Jasay, A. de (2002), Justice and its Surroundings, Liberty Fund, Indianapolis.

Joseph, N. (2011), "The impartial spectator, amour propre, and consequences of the secular gaze: Rousseau's and Adam Smith's responses to Mandeville", Lumen, 30, pp. 33-44. (http://id.erudit.org/iderudit/1007714ar)

Khalil, E. L. (2001), "Adam Smith and three theories of altruism”, Recherches Économiques de Louvain, 4, vol 67: 421-435.

Leoni, B. (1991), Freedom and the Law, Indianapolis: Liberty Fund (originally published in 1961, by Van Norstrand Company, Princeton). 
Levitt, S.D., List, J.A. (2007), "What do laboratory experiments measuring social preferences reveal about the real world?", Journal of Economic Perspectives, 21(2), spring, pp. 153-174.

Locke, J. (1689), Two Treatises of Government, ed. Thomas Hollis (London: A. Millar et al., 1764), downloaded on Nov. 17, 2014 from http://oll.libertyfund.org/titles/222.

Lodge, A. (2009); Criminal responsibility for intrusions on the rights of innocent persons: the limits of self-defence, necessity and duress, Durham theses, Durham, Durham University. Available at Durham E-Theses Online:

http://etheses.dur.ac.uk/2102/

Mack, E. (2008), "Individual rights", in Ronald Hamowy (ed), The Encyclopedia of Libertarianism, Sage, London: 244-247.

Manner, M. and Gowdy, J. (2010), “The evolution of social and moral behaviour: evolutionary insights for public policy”, Ecological Economics, 69 (4): 753-761. Mezzetti, E. (1997), "Stato di necessità", Digesto delle discipline penalistiche, available online at www.leggiditalia.it/catalogo/interpretazione/45: 1-23.

Posner, R.A. (1979), "Utilitarianism, economics, and legal theory”, Journal of Legal Studies, 8 (1): 103-140.

Raphael, D.D. (2007), The Impartial Spectator, Oxford: Oxford University Press. Ridley, M. (1996), The Origins of Virtue, Penguin Books, London.

Romano, M. (1995), Commentario sistematico del codice penale, (II edition), Giuffrè, Milano.

Rothbard, M. N. (1982), The Ethics of Liberty, New York University Press, New York.

Sen, A. (2009), The Idea of Justice, Allen Lane, London.

Zak, P. and Knack, S. (2001), “Trust and growth”, Economic Journal, 111 (470), March, pp. 295-321. 


\section{Endnotes}

${ }^{1}$ See Manner and Gowdy (2010).

${ }^{2}$ The Impartial Spectator plays a critical role in the Scottish approach to moral behaviour. As pointed out in Joseph (2011, p. 34), Mandeville "reads the gaze as a means by which power maintains itself and renders us tractable and governable subjects". Hutcheson, Hume and Smith will then develop this gaze into a self-imposed behavioural rule, and clearly underscore the distinction between self-interest and own interest (Mandeville had a similar distinction, between self love and self liking). The former term identifies unconstrained maximization of the individual's satisfaction, as suggested by the rationalists (e.g., Lord Shaftesbury). By contrast, the latter term relates to the fact individual actions are constrained by morality and justice.

${ }^{3}$ The rewards to the donor (self-complacency and recipient's gratefulness) and the benefits to the external beneficiary are frequently highly correlated, but they are of course different variables.

${ }^{4}$ It should be noticed that the benefits obtained by recipient $B$ as a result of $A$ 's altruistic behaviour might be mitigated - or even reversed - by B's knowing that he is morally obligated towards $A$, and that he might have to reciprocate at some point. Hence, according to the definition provided in the text, altruism is not necessarily welfare improving. This paper, however, deals with an understanding of altruism as failing solely as a result of the altruists' failure fully to account for positive spillover effects. Other considerations will have to be addressed in a later paper.

${ }^{5}$ See for example Zak and Knack (2001), Carpenter and Knowles Myers (2007) and Bjørnskov (2012).

${ }^{6}$ For example, the negative correlation between tax pressure and altruism applies to the USA, where philanthropic donations represent a remarkably constant percentage (2\%) of disposable income. See http://philanthropy.com/article/The-Stubborn-2-Giving-Rate/139811/ downloaded on November 4, 2014.

${ }^{7}$ Consequentialism is the normative principle according to which the desirability of an action depends on the consequences that it produces, regardless of the intrinsic moral nature of the action itself. See for example http://plato.stanford.edu/entries/consequentialism/\#Bib, downloaded on August 18, 2014.

${ }^{8}$ Art. 54 (1): "the law does not punish those who have acted in order to avoid serious damage to themselves or to other parties. However, the actor should not have been himself the intentional cause of the damage, the damage cannot be remedied through other means, and the action must be proportional to the impending peril" (our emphasis).

${ }^{9}$ See for example Cass. pen., Sez. V, 30/04/2010, n. 26159, which confirmed the sentence against an individual who had kidnapped and detained a girl for four days in order to stop her cocaine dependence.

${ }^{10}$ Cass. pen., Sez. Unite, 18/12/2008, n. 2437.

${ }^{11}$ Cass. civ., Sez. III, 23/02/2007, n. 4211.

${ }^{12}$ See A (Children), Re [2000] EWCA Civ 254 (22 September 2000), VI.

${ }^{13}$ There can be "physical aggression" also by mere cheating or lying. When A sells a faulty car to B by telling $B$ that the car is in perfect conditions, $A$ is violating B's property by stealing the latter's money received as price. By contrast, there is no aggression if $A$ tries to persuade $B$ to buy the car despite its declared faults (e.g. the chassis has been damaged by a major accident), even if the ordinary wear-andtear conditions of the car are not disclosed (e.g., the engine has clocked up 100,000 miles and might need important maintenance). 
${ }^{14}$ This view is also held by Block (2003), although other libertarians share a different view. For example, Rothbard (1982: chapter 19) claims that if a contract consists in a promise to perform, rather than a transfer of property, the contract is not binding and breach of contract should involve no sanctions.

${ }^{15}$ See page 3 of his opinion in Stovin and another v. Norfolk County Council, [1996] UKHL 15 (a not directly relevant case); and also the extensive survey presented by Hyman (2006) with regard to the USA.

${ }^{16}$ Altruistic help regards services for which Andrew asks limited or no compensation. However, a refusal to help does not correspond to "omissive coercion". Omissive coercion refers to a situation in which Andrew has a duty to help, but refrains from doing so unless Bob complies with Andrew's request. By contrast, in our context Andrew has no duty to intervene, other than what his conscience suggests or what agreed-upon contracts bind him to do.

17 "Honour" and "other legal interest" are mentioned - for example -- by the German legislator (§ 34 crim. code). The same holds also in Italy, where both academic interpretation and the judiciary agree that the notion of "serious personal damage" includes "honour" (Romano, 535; Crespi-Forti-Zuccalà, sub art. 54, VII, 1).

${ }^{18}$ Curiously enough, the notion of "human flourishing" (eudaimonia) originates from the Greek philosophical tradition, according to which flourishing was a spiritual, rather than a physical process. In ancient Greece, individual liberty meant freedom from material concerns, which implied the ability to live in poverty, rather than affluence.

${ }^{19}$ Eminent scholars have devoted much effort to justifying this notion of relative equality: see for instance Sen (2009), who moves from the notion of opportunity to that of capability. Relative egalitarianism is expedient in avoiding broader institutional issues. For example, it ensures that an egalitarian, low-income Swede does not feel compelled to give away most of his wealth to a middleincome Bangladeshi. Yet, even relative egalitarianism remains puzzling. For example, it is not evident that a low-income individual in a poor egalitarian society enjoys more opportunities to flourish (liberty) than a middle-income earner in an affluent community.

${ }^{20}$ As a matter of fact, things are more complex. When Andrew donates to Bob, Bob's position usually changes for the better, and Bob's chances for future flourishing are positively affected. This might justify a tax on Bob's extra benefits, which however would negatively affect Andrew's feelings and flourishing. More generally, the egalitarian literature is ambiguous about the time when the options should be equalized: should income equalization take place at birth? at the beginning of working age? Or perhaps at the end of each year, under the tacit assumption that one's plans to flourish are independent of the expectations about future income? Or of his ability to make money and improve his and/or his family's living standards?

${ }^{21} \mathrm{~A}$ variant of this approach is known as "procedure-based contractarianism", which is characterized by the presence of qualified-majority voting, and the belief that constitutional constraints can effectively limit rent-seeking. See the review article by Congleton (2014).

${ }^{22}$ Electoral absenteeism is not perceived as a sign of disapproval of the notion of procedural legitimacy, but rather as lack of interest or disapproval of the candidates. In other words, absenteeism is no evidence of delegitimized law making.

${ }^{23}$ See for example Christie (1999) and, more recently, Lodge (2009). 
${ }^{24}$ According to the Italian system, the judge checks for proportionality. France is more tolerant towards the aggressor in that the judge only checks whether there is a significant imbalance between the act and the peril the actor tries to neutralize. In Germany, B's material interest protected by actor A must be greater than the damage that $A$ provokes to $C$, unless $B$ is a next of kin to $A$. The same criterion holds in Japan and Spain, but without the qualifications regarding kinship between $A$ and $B$. 